\title{
Procedure for the measurements of lattice parameters and crystallite sizes of carbon materials by $\mathrm{X}$-ray diffraction. \\ (Revised at April 2005)
}

\section{日本学術振興会 第117委員会}

The 117 Committee of the Japan Society for the Promotion of Sciences

\begin{abstract}
Purpose : The purpose of this procedure is to standardize the procedure for the X-ray diffraction measurements of lattice parameters and crystallite sizes of carbon materials. This specification is expected to be used to characterize the structure not only in research laboratories but also in companies producing and using carbon materials. By utilizing the present procedure, more reliable and reproducible structural parameters could be measured, even though some of the determined parameters do not satisfy their exact scientific meanings. For example, the values of measured crystallite sizes depend not only on size of crystals but also on the strain in the crystals.

Abstract : This specification has been called the "Gakushin" method and has been commonly used in Japan. The method gave reliable values of lattice constants and crystallite sizes of carbon materials having a relatively high degree of graphitization. The diffraction peaks 002, 004, 110, 112 and 006 enabled us to compare data measured in different laboratories. The principal points of this specification are as follows : 1) the diffraction profiles observed must be corrected for the line broadening due to different intensity factors, such as X-ray absorption, Lorentz-polarization factors and the atomic scattering factor ; 2) an internal standard of silicon must be used in order to avoid the shifting and broadening of diffraction profiles mainly due to the instrument used ; and 3) a mixture of carbon sample with standard silicon must be packed in a thin sample holder for X-ray diffraction $(0.2 \mathrm{~mm}$ thickness $)$.
\end{abstract}

KEYWORDS : Graphitization, X-ray diffraction, Crystal structure

\section{5. 標準シリコン}

\section{1. 適応範囲}

この測定方法は, X線回折装置を用いて炭素材料粉末の回折X線 を測定し,これによって炭素材料の格子定数と結晶子の大きさの 測定を行う場合の一般的事項について規定する。さらに,この手 法が適応される炭素材料は, 少なくとも以下に述べるX線粉末回 折測定法において明確な002回折線のピークプロファイルが得ら れることとする。

\section{2. 共通事項および用語の定義}

この手法での共通事項および用いる主な用語の定義は, JIS K 0131 X線回折分析通則に準ずる。

\section{3. 装置}

X 線回折装置の基本構成は, JIS K 0131 に準ずることとする。

\section{4. 試料および調整方法}

供試炭素材料から適当量を採取し,メノウ乳鉢などで全量が 150 メッシュ標準ふるい $(100 \mu \mathrm{m})$ を通過するように粉砕し試料 とする。ただし, 粉砕によって生じる構造変化, または污染の可 能性については注意を要する。
回折角度と回折半価幅が保証されており,粒度分布などの技術 データも公表されている市販のX線回折標準用の高純度シリコ ン粉末を使用すること。

\section{X線回折測定用試料}

試料に対して10あるいは20mass％*1 標準シリコンを採取, 混合 L, X線回折測定用試料とする。炭素試料と標準シリコンとの混 合が十分均一であることが必要であって, そのためには試料板に充 填する前にメノウ乳鉢中で十分混合することが必須である。

測定用試料はX 線回折装置付属の試料空の大きさが $15 \sim 18 \times$ $20 \mathrm{~mm}$, 深さ $0.2 \mathrm{~mm}$ の試料板 (ガラスフォルダ) にできるだけ均 一に薄く, 高密度に充填する。

使用したシリコン粉末の妥当性の判定として, 炭素試料と混合 して測定したときのシリコン 331 および 422 回折線のピークプロ ファイルが $\mathrm{Cu} \mathrm{K} \alpha_{1}, \mathrm{Cu} \mathrm{K} \alpha_{2}$ 線に分離されていること。さらに, シ リコン 111 回折ピークの半価幅が $0.2^{\circ}$ 以下であることが使用の 必須条件である。

*1 標準シリコン混合量は試料の黑鉛化の程度によって適宜変えるこ とが望ましい。また, 炭素の回折強度と標準シリコンの回折強度が ほぼ同程度にすることが好ましい。 


\section{7. 回折ピークプロファイルの測定}

$\mathrm{X}$ 線は $\mathrm{Cu} \mathrm{K} \alpha$ 線を用い, $\mathrm{Cu} \mathrm{K} \beta$ 線はニッケル $(\mathrm{Ni})$ フィルター または黒鉛結晶カウンターモノクロメータによって除く。X線源 への印加電圧および電流は $30 \sim 50 \mathrm{kV}$ おび $30 \mathrm{~mA}$ 以上とする。 炭素の002,004,006, 110 および112回折線のピークプロファイ ルをX線回折計にて測定する。各回折線のピークプロファイル の測定の際のX線回折計のスリット系の標準的条件をTable 1 に 示す。

回折線のピークプロファイルは, 計数管の走査速度を $0.25 \% \mathrm{~min}$ とした連続走査法, あるいは $0.02^{\circ}$ 以下のサンプリング間隔で 2 秒 以上*2の積算時間でのステップスキャン法 (FT 法)によって測 定する。ステップスキャン法の場合, 精度高く測定する場合には 積算時間をより長くすることが推奨される。

炭素の各回折線の標準として用いる標準シリコンの回折線の 指数 $h k l$ および回折角 $2 \theta$ を Table 2 に示す。標準シリコンの回折 角度は, $\mathrm{K} \alpha_{1}$ 線によるものと $\mathrm{K} \alpha_{\mathrm{m}}$ 線による值をそれぞれ記した。

その 1 組の回折線のピークプロファイルは必ず連続して, 記録・ 測定しなければならない。

\section{8. 回折ピークプロファイルの補正}

炭素の各回折ピークプロファイルについてはローレンツ $(L)$, 偏光因子 $(P)$, 吸収因子 $(A)$ および炭素の原子散乱因子 $\left(f_{c}\right)$ に関 する補正を行う必要がある*3。

$$
\begin{aligned}
& \text { ローレンツ }(L) \\
& L=\frac{1}{\sin ^{2} \theta \cdot \cos \theta}
\end{aligned}
$$

Table 1 Slits systems recommended for the measurement of each reflections (goniometer radius : $185 \mathrm{~mm}$ ).

\begin{tabular}{|c|c|c|c|c|}
\hline \multicolumn{2}{|c|}{$h k l$ reflections of carbon } & 002 & 004 & $110,112,006$ \\
\hline \multirow{3}{*}{ Slit system } & Divergence slit & $1 / 2^{\circ}$ & $1^{\circ}$ & $2^{\circ}$ \\
\cline { 2 - 5 } & Receiving slit & $0.15 \mathrm{~mm}$ & $0.15 \mathrm{~mm}$ & $0.15 \mathrm{~mm}$ \\
\cline { 2 - 5 } & Scattering slit & $1 / 2^{\circ}$ & $1^{\circ}$ & $2^{\circ}$ \\
\hline
\end{tabular}

Table 2 Diffraction indices and angles of the reflections of the silicon standard, which are used as standards for the corresponding carbon reflections.

\begin{tabular}{|c|c|c|c|}
\hline \multicolumn{2}{|c|}{ Carbon } & \multicolumn{2}{c|}{ Standard silicon } \\
\hline$h k l$ & $2 \theta_{C}\left({ }^{\circ}\right)$ & $h k l$ & $\left.2 \theta_{\mathrm{Si}}{ }^{\circ}\right)$ \\
\hline 002 & $25.9 \sim 26.6$ & 111 & $\begin{array}{l}\alpha_{1} 28.443, \\
\alpha_{\mathrm{m}} 28.467\end{array}$ \\
\hline 004 & $53.2 \sim 54.7$ & 311 & $\begin{array}{l}\alpha_{1} 56.123, \\
\alpha_{\mathrm{m}} 56.174\end{array}$ \\
\hline 110 & near 77.6 & 331 & $\begin{array}{l}\alpha_{1} 76.378, \\
\alpha_{\mathrm{m}} 76.452\end{array}$ \\
\hline 112 and 006 & 83.6 and near 87 & 422 & $\begin{array}{l}\alpha_{1} 88.032, \\
\alpha_{\mathrm{m}} 88.124\end{array}$ \\
\hline
\end{tabular}

偏光因子 $(P)$

$$
P=\frac{1+\cos ^{2} 2 \theta \cdot \cos ^{2} 2 \theta^{\prime}}{1+\cos ^{2} 2 \theta^{\prime}}
$$

ここで, $\theta$ はゴニオメータの角度である。 $\theta^{\prime}$ は単色化の手法に よって異なる。咕はカウンターモノクロメータを使用したときの モノクロメータ結晶の回折角であり, 黒鉛モノクロメータを用いた 場合は $\theta^{\prime}=13.28^{\circ}$ である。カウンターモノクロメー夕を使わな いとき $\left(\mathrm{Ni}\right.$ フィルー使用のとき) は $\theta^{\prime}=0^{\circ}$ である。

吸収因子 $(A)$

$$
A=\left(1-\frac{\sin (2 \theta)}{2 \mu^{\prime} b_{r}}\right)\left(1-\exp \left(\frac{-2 \mu^{\prime} t}{\sin \theta}\right)\right)+\frac{2 t \cos \theta}{b_{r}} \exp \left(\frac{-2 \mu^{\prime} t}{\sin \theta}\right)
$$

ここで， $\theta$ はゴニオメータの角度である。 $\mu^{\prime}$ は試料の見かけの 線吸収係数であり，シリコン添加量が 10 mass \%のとき $\mu^{\prime}=100$ $\left[\mathrm{mm}^{-1}\right]$ ，および20mass \%のとき $\mu^{\prime}=160\left[\mathrm{~mm}^{-1}\right]$ を代入する。 $\mathrm{t}$ はサンプルフォルダにおける試料深さ $0.2 \mathrm{~mm}$ である。 $b_{r}$ は試料 面におけるX線の照射幅であり, 次式で与えられる。

$$
b_{r}=R_{\text {gonio }} \sin \beta_{D S} \quad[\mathrm{~mm}]
$$

ここで, $\beta_{D S}$ は発散スリット (DS) 幅 $\left[{ }^{\circ}\right.$ (degree) $), R_{\text {gonio }}$ はゴニ オメータ半径 (ここでは $\left.R_{\text {gonio }}=185 \mathrm{~mm}\right)$ である。

原子散乱因子 $\left(f_{c}\right) * 4$

$$
\begin{aligned}
f_{c}= & 2.26069 \exp \left(-0.226907 s^{2}\right)+1.56165 \exp \left(-0.00656665 s^{2}\right) \\
& +1.05075 \exp \left(-0.0975618 s^{2}\right) \\
& +0.839259 \exp \left(-0.5555949 s^{2}\right)+0.286977
\end{aligned}
$$

ここで, $s=\frac{\sin \theta}{\lambda}$ で, $\theta$ はゴニオメータの角度, $\lambda$ は $\mathrm{CuK} \alpha$ の波 長で, $\lambda=0.15419 \mathrm{~nm}$ を代入する。

各測定角度における回折強度を(1) 式から（5) 式の各種の補 正值で割る。簡便的な補正については, 各測定角度ついて事前に 計算した補正因子で各回折強度を割る方法，またはその近似式 （6）で与えられる補正值 $\boldsymbol{F C T}=\boldsymbol{L} \cdot \boldsymbol{P} \cdot \boldsymbol{A} \cdot \boldsymbol{f}_{\boldsymbol{c}} \mathbf{2}$ で回折強度を割る方 法が利用できる。

002 回折線に対しての補正因子および近似式 (6) の係数を Table 3 およびTable 4, 004 回折線に対するそれらをTable 5 およびTable 6,

*2 $18 \mathrm{~kW}$ の回転対陰極タイプの場合は, 積算時間は 1 秒以上でよい。 積算時間が短くても回折強度が強いときは, 管電流值を低下させる。

*3 観測された002回折線のピークプロファイルの半価幅が $0.5^{\circ}$ 以下 の場合はこの補正を省略してもよい。

*4 International Tables for X-ray Crystallography, Vol.C, International Union of Crystallography, 1999 より。ただし,出典の数值は, X線の波 長の単位にはオングストロームを使用しているので注意されたい。

*5 110, 112 および006回折線については, 強度補正の格子定数および 結晶子の大きさへの影響は少なく，省略することができる。ただし， 回折ピークプロファイルの対称性を議論する場合および結晶子の大 きさをより正確に求めたい場合などには,この補正が必要である。 
Table 3 Correction factors for the 002 reflection (slit system : $1 / 2^{\circ}-0.15 \mathrm{~mm}-1 / 2^{\circ}$, goniometer radius : $185 \mathrm{~mm}$ ).

\begin{tabular}{|c|c|c|c|c|c|c|c|c|c|}
\hline \multirow[b]{2}{*}{$2 \theta$} & \multicolumn{2}{|c|}{ Si $10 \%$} & \multicolumn{2}{|c|}{ Si $20 \%$} & \multirow[b]{2}{*}{$2 \theta$} & \multicolumn{2}{|c|}{ Si $10 \%$} & \multicolumn{2}{|c|}{ Si $20 \%$} \\
\hline & Ni filter & $\begin{array}{c}\text { Mono- } \\
\text { chromator }\end{array}$ & Ni filter & $\begin{array}{l}\text { Mono- } \\
\text { chromator }\end{array}$ & & Ni filter & $\begin{array}{l}\text { Mono- } \\
\text { chromator }\end{array}$ & Ni filter & $\begin{array}{l}\text { Mono- } \\
\text { chromator }\end{array}$ \\
\hline 20.0 & 3.52 & 3.49 & 3.52 & 3.49 & 26 & 1.60 & 1.60 & 1.60 & 1.60 \\
\hline 20.2 & 3.43 & 3.40 & 3.42 & 3.39 & 26.2 & 1.57 & 1.56 & 1.56 & 1.56 \\
\hline 20.4 & 3.33 & 3.30 & 3.32 & 3.30 & 26.4 & 1.53 & 1.52 & 1.53 & 1.52 \\
\hline 20.6 & 3.24 & 3.21 & 3.23 & 3.21 & 26.6 & 1.49 & 1.49 & 1.49 & 1.49 \\
\hline 20.8 & 3.15 & 3.13 & 3.15 & 3.12 & 26.8 & 1.46 & 1.45 & 1.45 & 1.45 \\
\hline 21.0 & 3.07 & 3.04 & 3.06 & 3.04 & 27.0 & 1.42 & 1.42 & 1.42 & 1.42 \\
\hline 21.2 & 2.98 & 2.96 & 2.98 & 2.95 & 27.2 & 1.39 & 1.38 & 1.39 & 1.38 \\
\hline 21.4 & 2.90 & 2.88 & 2.90 & 2.88 & 27.4 & 1.35 & 1.35 & 1.35 & 1.35 \\
\hline 21.6 & 2.83 & 2.80 & 2.82 & 2.80 & 27.6 & 1.32 & 1.32 & 1.32 & 1.32 \\
\hline 21.8 & 2.75 & 2.73 & 2.75 & 2.73 & 27.8 & 1.29 & 1.29 & 1.29 & 1.29 \\
\hline 22.0 & 2.68 & 2.66 & 2.67 & 2.65 & 28.0 & 1.26 & 1.26 & 1.26 & 1.26 \\
\hline 22.2 & 2.61 & 2.59 & 2.60 & 2.58 & 28.2 & 1.23 & 1.23 & 1.23 & 1.23 \\
\hline 22.4 & 2.54 & 2.52 & 2.53 & 2.52 & 28.4 & 1.20 & 1.20 & 1.20 & 1.20 \\
\hline 22.6 & 2.47 & 2.46 & 2.47 & 2.45 & 28.6 & 1.18 & 1.17 & 1.17 & 1.17 \\
\hline 22.8 & 2.41 & 2.39 & 2.40 & 2.39 & 28.8 & 1.15 & 1.15 & 1.15 & 1.15 \\
\hline 23.0 & 2.35 & 2.33 & 2.34 & 2.33 & 29.0 & 1.12 & 1.12 & 1.12 & 1.12 \\
\hline 23.2 & 2.29 & 2.27 & 2.28 & 2.27 & 29.2 & 1.10 & 1.10 & 1.10 & 1.10 \\
\hline 23.4 & 2.23 & 2.21 & 2.22 & 2.21 & 29.4 & 1.07 & 1.07 & 1.07 & 1.07 \\
\hline 23.6 & 2.17 & 2.16 & 2.17 & 2.15 & 29.6 & 1.05 & 1.05 & 1.05 & 1.05 \\
\hline 23.8 & 2.11 & 2.10 & 2.11 & 2.10 & 29.8 & 1.02 & 1.02 & 1.02 & 1.02 \\
\hline 24.0 & 2.06 & 2.05 & 2.06 & 2.05 & 30.0 & 1 & 1 & 1 & 1 \\
\hline 24.2 & 2.01 & 2.00 & 2.01 & 2.00 & 30.2 & 0.98 & 0.98 & 0.98 & 0.98 \\
\hline 24.4 & 1.96 & 1.95 & 1.96 & 1.95 & 30.4 & 0.96 & 0.96 & 0.96 & 0.96 \\
\hline 24.6 & 1.91 & 1.90 & 1.91 & 1.90 & 30.6 & 0.93 & 0.93 & 0.93 & 0.93 \\
\hline 24.8 & 1.86 & 1.85 & 1.86 & 1.85 & 30.8 & 0.91 & 0.91 & 0.91 & 0.91 \\
\hline 25.0 & 1.82 & 1.81 & 1.81 & 1.81 & 31.0 & 0.89 & 0.89 & 0.89 & 0.89 \\
\hline 25.2 & 1.77 & 1.76 & 1.77 & 1.76 & 31.2 & 0.87 & 0.87 & 0.87 & 0.87 \\
\hline 25.4 & 1.73 & 1.72 & 1.73 & 1.72 & 31.4 & 0.85 & 0.86 & 0.85 & 0.86 \\
\hline 25.6 & 1.69 & 1.68 & 1.68 & 1.68 & 31.6 & 0.84 & 0.84 & 0.84 & 0.84 \\
\hline 25.8 & 1.64 & 1.64 & 1.64 & 1.64 & 31.8 & 0.82 & 0.82 & 0.82 & 0.82 \\
\hline & & & & & 32.0 & 0.80 & 0.80 & 0.80 & 0.80 \\
\hline
\end{tabular}

Table 4 Coefficients $C_{i}$ in equation (6) for the 002 reflection (slit system $: 1 / 2^{\circ}-0.15 \mathrm{~mm}-1 / 2^{\circ}$, goniometer radius $: 185 \mathrm{~mm}$ ).

\begin{tabular}{|c|c|c|c|c|}
\hline & \multicolumn{2}{|c|}{ Si 10\% } & \multicolumn{2}{c|}{ Si 20\% } \\
\cline { 2 - 5 } & Ni filter & Monochromator & Ni filter & Monochromator \\
\hline $\mathrm{C}_{1}$ & 49.685004 & 48.946431 & 49.484622 & 48.748923 \\
\hline $\mathrm{C}_{2}$ & -5.5115289 & -5.4253726 & -5.4871704 & -5.4013802 \\
\hline $\mathrm{C}_{3}$ & $2.4582945 \times 10^{-1}$ & $2.4192155 \times 10^{-1}$ & $2.4468839 \times 10^{-1}$ & $2.4079817 \times 10^{-1}$ \\
\hline $\mathrm{C}_{4}$ & $-5.1023579 \times 10^{-3}$ & $-5.0208087 \times 10^{-3}$ & $-5.0779991 \times 10^{-3}$ & $-4.9968337 \times 10^{-3}$ \\
\hline $\mathrm{C}_{5}$ & $4.0959824 \times 10^{-5}$ & $4.0304482 \times 10^{-5}$ & $4.0760928 \times 10^{-5}$ & $4.0108747 \times 10^{-5}$ \\
\hline
\end{tabular}

そして 110 尔よび 112 回折線に対するそれらを Table 7 および

Table 8 に示す *5。

$$
F C T=C_{1}+C_{2} \cdot(2 \theta)+C_{3} \cdot(2 \theta)^{2}+C_{4} \cdot(2 \theta)^{3}+C_{5} \cdot(2 \theta)^{4}
$$

ここで, $\theta$ はゴニオメータの角度である。

このようにして得られた回折ピークプロファイルについて, 以 下の作業を行う。

\section{9. 回折ピークプロファイルの解析}

強度補正した回折ピークプロファイルから以下の手順で回折 角 $2 \theta$ を測定し, 格子定数を決定する。

\section{(1) ベースラインの決定}

ベースラインは, 002 回折線の場合は $2 \theta=29^{\circ}, 004$ 回折線の場 合は $57^{\circ}, 110$ 回折線の場合は $75^{\circ}, 112$ 回折線の場合は $89^{\circ}$ を基 準とする (Fig.1参照)。

プロファイルフィッティング処理では, 解析精度を上げるため に, 回折ピークプロファイルを必要に応じて Savitsky-Golay 法な どで平滑化した後にベースラインの決定を行うことが望ましい。 さらに, 解析精度の向上のため, 測定角度範囲においてべースラ インの基点となる複数個の点を任意に選択し，互いに隣接する 2 点間を三次スプライン関数で補間してベースラインを決定して もよい。 
Table 5 Correction factors for the 004 reflection (slit system : $1^{\circ}-0.15 \mathrm{~mm}-1^{\circ}$, goniometer radius : $185 \mathrm{~mm}$ ).

\begin{tabular}{|c|c|c|c|c|c|c|c|c|c|}
\hline \multirow[b]{2}{*}{$2 \theta$} & \multicolumn{2}{|c|}{ Si $10 \%$} & \multicolumn{2}{|c|}{ Si $20 \%$} & \multirow[b]{2}{*}{$2 \theta$} & \multicolumn{2}{|c|}{ Si $10 \%$} & \multicolumn{2}{|c|}{ Si $20 \%$} \\
\hline & Ni filter & $\begin{array}{l}\text { Mono- } \\
\text { chromator }\end{array}$ & Ni filter & $\begin{array}{c}\text { Mono- } \\
\text { chromator }\end{array}$ & & $\mathrm{Ni}$ filter & $\begin{array}{l}\text { Mono- } \\
\text { chromator }\end{array}$ & Ni filter & $\begin{array}{l}\text { Mono- } \\
\text { chromator }\end{array}$ \\
\hline 50.0 & 1.67 & 1.65 & 1.67 & 1.65 & 56.0 & 1.07 & 1.07 & 1.07 & 1.07 \\
\hline 50.2 & 1.65 & 1.62 & 1.64 & 1.62 & 56.2 & 1.06 & 1.05 & 1.06 & 1.05 \\
\hline 50.4 & 1.62 & 1.60 & 1.62 & 1.60 & 56.4 & 1.04 & 1.04 & 1.04 & 1.04 \\
\hline 50.6 & 1.59 & 1.58 & 1.59 & 1.57 & 56.6 & 1.03 & 1.03 & 1.03 & 1.03 \\
\hline 50.8 & 1.57 & 1.55 & 1.57 & 1.55 & 56.8 & 1.01 & 1.01 & 1.01 & 1.01 \\
\hline 51.0 & 1.55 & 1.53 & 1.55 & 1.53 & 57.0 & 1 & 1 & 1 & 1 \\
\hline 51.2 & 1.52 & 1.51 & 1.52 & 1.50 & 57.2 & 0.99 & 0.99 & 0.99 & 0.99 \\
\hline 51.4 & 1.50 & 1.48 & 1.50 & 1.48 & 57.4 & 0.97 & 0.97 & 0.97 & 0.97 \\
\hline 51.6 & 1.48 & 1.46 & 1.48 & 1.46 & 57.6 & 0.96 & 0.96 & 0.96 & 0.96 \\
\hline 51.8 & 1.45 & 1.44 & 1.45 & 1.44 & 57.8 & 0.95 & 0.95 & 0.95 & 0.95 \\
\hline 52.0 & 1.43 & 1.42 & 1.43 & 1.42 & 58.0 & 0.94 & 0.94 & 0.94 & 0.94 \\
\hline 52.2 & 1.41 & 1.40 & 1.41 & 1.40 & 58.2 & 0.92 & 0.92 & 0.92 & 0.93 \\
\hline 52.4 & 1.39 & 1.38 & 1.39 & 1.38 & 58.4 & 0.91 & 0.91 & 0.91 & 0.91 \\
\hline 52.6 & 1.37 & 1.36 & 1.37 & 1.36 & 58.6 & 0.90 & 0.90 & 0.90 & 0.90 \\
\hline 52.8 & 1.35 & 1.34 & 1.35 & 1.34 & 58.8 & 0.89 & 0.89 & 0.89 & 0.89 \\
\hline 53.0 & 1.33 & 1.32 & 1.33 & 1.32 & 59.0 & 0.88 & 0.88 & 0.88 & 0.88 \\
\hline 53.2 & 1.31 & 1.30 & 1.31 & 1.30 & 59.2 & 0.86 & 0.87 & 0.86 & 0.87 \\
\hline 53.4 & 1.29 & 1.28 & 1.29 & 1.28 & 59.4 & 0.85 & 0.86 & 0.85 & 0.86 \\
\hline 53.6 & 1.27 & 1.26 & 1.27 & 1.26 & 59.6 & 0.84 & 0.85 & 0.84 & 0.85 \\
\hline 53.8 & 1.25 & 1.24 & 1.25 & 1.24 & 59.8 & 0.83 & 0.84 & 0.83 & 0.84 \\
\hline 54.0 & 1.23 & 1.23 & 1.23 & 1.23 & 60.0 & 0.82 & 0.83 & 0.82 & 0.83 \\
\hline 54.2 & 1.22 & 1.21 & 1.22 & 1.21 & 60.2 & 0.81 & 0.82 & 0.81 & 0.82 \\
\hline 54.4 & 1.20 & 1.19 & 1.20 & 1.19 & 60.4 & 0.80 & 0.81 & 0.80 & 0.81 \\
\hline 54.6 & 1.18 & 1.18 & 1.18 & 1.18 & 60.6 & 0.79 & 0.80 & 0.79 & 0.80 \\
\hline 54.8 & 1.17 & 1.16 & 1.17 & 1.16 & 60.8 & 0.78 & 0.79 & 0.78 & 0.79 \\
\hline 55.0 & 1.15 & 1.14 & 1.15 & 1.14 & 61.0 & 0.77 & 0.78 & 0.77 & 0.78 \\
\hline 55.2 & 1.13 & 1.13 & 1.13 & 1.13 & 61.2 & 0.76 & 0.77 & 0.76 & 0.77 \\
\hline 55.4 & 1.12 & 1.11 & 1.12 & 1.11 & 61.4 & 0.75 & 0.76 & 0.75 & 0.76 \\
\hline 55.6 & 1.10 & 1.10 & 1.10 & 1.10 & 61.6 & 0.74 & 0.75 & 0.74 & 0.75 \\
\hline 55.8 & 1.09 & 1.08 & 1.09 & 1.08 & 61.8 & 0.73 & 0.74 & 0.73 & 0.74 \\
\hline & & & & & 62.0 & 0.73 & 0.73 & 0.73 & 0.73 \\
\hline
\end{tabular}

Table 6 Coefficients $C_{i}$ in equation (6) for the 004 reflection (slit system : $1^{\circ}-0.15 \mathrm{~mm}-1^{\circ}$, goniometer radius $: 185 \mathrm{~mm}$ ).

\begin{tabular}{|c|c|c|c|c|}
\hline & \multicolumn{2}{|c|}{ Si 10\% } & \multicolumn{2}{c|}{ Si $20 \%$} \\
\cline { 2 - 5 } & Ni filter & Monochromator & Ni filter & Monochromator \\
\hline $\mathrm{C}_{1}$ & 72.439651 & 68.973946 & 72.263707 & 68.805429 \\
\hline $\mathrm{C}_{2}$ & -4.1085535 & -3.9023507 & -4.0978341 & -3.8921019 \\
\hline $\mathrm{C}_{3}$ & $9.0951562 \times 10^{-2}$ & $8.6269091 \times 10^{-2}$ & $9.0702845 \times 10^{-2}$ & $8.6031594 \times 10^{-2}$ \\
\hline $\mathrm{C}_{4}$ & $-9.1973524 \times 10^{-4}$ & $-8.7159290 \times 10^{-4}$ & $-9.1713173 \times 10^{-4}$ & $-8.6910890 \times 10^{-4}$ \\
\hline $\mathrm{C}_{5}$ & $3.5595705 \times 10^{-6}$ & $3.3710395 \times 10^{-6}$ & $3.5492318 \times 10^{-6}$ & $3.3611820 \times 10^{-6}$ \\
\hline
\end{tabular}

Caution : digit numbers of coefficient should be kept

\section{（2）格子定数の決定}

ベースラインから図形の高さ $2 / 3$ の位置でベースラインに平行 線を引き，その図形によって区切られる中点を回折角度とする

(Fig.2参照)。

なお, 炭素および標準シリコンの各回折ピークプロファイルで は, Fig.2 中に示したごとく, $\mathrm{K} \alpha_{1} \cdot \mathrm{K} \alpha_{2}$ 線の分離がみられる場合が ある。記録紙上の場合, $\mathrm{K} \alpha_{1} \cdot \mathrm{K} \alpha_{2}$ 線の分離が非常に明瞭な場合 は, $\mathrm{K} \alpha_{1}$ ピークの先端から高角度側のすそへ想定線を引き, 回折 角を求めてもよい(Fig.2C参照)。

プロファイルフィッティング処理では適当なフィッティング関 数 (例えば, Voigt 関数, Pseudo-Voigt関数, PearsonVII 関数など)
でピーク頂点を決定し, フィッティング関数の変数值より, 高さ 2/3の位置でその図形によって区切られる中点, すなわち回折角 度を求めてもよい $($ Fig.3 参照)。その際のプロファイルフィッテ イングの信頼性は次式の $R$ 因子により評価する。

$$
R=\frac{\sum_{2 \theta}\left|I(2 \theta)-P_{r}(2 \theta)\right|}{\sum_{2 \theta} I(2 \theta)} \times 100
$$

ここで, $I(2 \theta)$ および $P_{r}(2 \theta)$ は, それぞれ実測プロファイルお よびフィッティングプロファイルを表す。 $R$-因子の值はできる だけ小さい值で, 10 以下になることが望ましい。 
Table 7 Correction factors for the 110 and 112 reflections (slit system $: 2^{\circ}-0.15 \mathrm{~mm}-2^{\circ}$, goniometer radius $: 185 \mathrm{~mm}$ ).

\begin{tabular}{|c|c|c|c|c|c|c|c|c|c|}
\hline \multirow[b]{2}{*}{$2 \theta$} & \multicolumn{2}{|c|}{ Si $10 \%$} & \multicolumn{2}{|c|}{ Si $20 \%$} & \multirow[b]{2}{*}{$2 \theta$} & \multicolumn{2}{|c|}{ Si $10 \%$} & \multicolumn{2}{|c|}{ Si $20 \%$} \\
\hline & Ni filter & $\begin{array}{c}\text { Mono- } \\
\text { chromator }\end{array}$ & Ni filter & $\begin{array}{c}\text { Mono- } \\
\text { chromator }\end{array}$ & & Ni filter & $\begin{array}{c}\text { Mono- } \\
\text { chromator }\end{array}$ & Ni filter & $\begin{array}{c}\text { Mono- } \\
\text { chromator }\end{array}$ \\
\hline 75.0 & 1.40 & 1.39 & 1.40 & 1.38 & 82.0 & 1.09 & 1.09 & 1.09 & 1.09 \\
\hline 75.2 & 1.39 & 1.38 & 1.39 & 1.37 & 82.2 & 1.08 & 1.08 & 1.08 & 1.08 \\
\hline 75.4 & 1.38 & 1.36 & 1.38 & 1.36 & 82.4 & 1.08 & 1.07 & 1.08 & 1.07 \\
\hline 75.6 & 1.37 & 1.35 & 1.37 & 1.35 & 82.6 & 1.07 & 1.07 & 1.07 & 1.07 \\
\hline 75.8 & 1.36 & 1.34 & 1.36 & 1.34 & 82.8 & 1.06 & 1.06 & 1.06 & 1.06 \\
\hline 76.0 & 1.35 & 1.33 & 1.34 & 1.33 & 83.0 & 1.06 & 1.06 & 1.06 & 1.06 \\
\hline 76.2 & 1.34 & 1.32 & 1.33 & 1.32 & 83.2 & 1.05 & 1.05 & 1.05 & 1.05 \\
\hline 76.4 & 1.33 & 1.31 & 1.32 & 1.31 & 83.4 & 1.05 & 1.04 & 1.05 & 1.04 \\
\hline 76.6 & 1.31 & 1.30 & 1.31 & 1.30 & 83.6 & 1.04 & 1.04 & 1.04 & 1.04 \\
\hline 76.8 & 1.30 & 1.29 & 1.30 & 1.29 & 83.8 & 1.03 & 1.03 & 1.03 & 1.03 \\
\hline 77.0 & 1.29 & 1.28 & 1.29 & 1.28 & 84.0 & 1.03 & 1.03 & 1.03 & 1.03 \\
\hline 77.2 & 1.29 & 1.27 & 1.28 & 1.27 & 84.2 & 1.02 & 1.02 & 1.02 & 1.02 \\
\hline 77.4 & 1.28 & 1.27 & 1.27 & 1.26 & 84.4 & 1.02 & 1.02 & 1.02 & 1.02 \\
\hline 77.6 & 1.27 & 1.26 & 1.26 & 1.26 & 84.6 & 1.01 & 1.01 & 1.01 & 1.01 \\
\hline 77.8 & 1.26 & 1.25 & 1.26 & 1.25 & 84.8 & 1.01 & 1.01 & 1.01 & 1.01 \\
\hline 78.0 & 1.25 & 1.24 & 1.25 & 1.24 & 85.0 & 1 & 1 & 1 & 1 \\
\hline 78.2 & 1.24 & 1.23 & 1.24 & 1.23 & 85.2 & 0.99 & 0.99 & 0.99 & 0.99 \\
\hline 78.4 & 1.23 & 1.22 & 1.23 & 1.22 & 85.4 & 0.99 & 0.99 & 0.99 & 0.99 \\
\hline 78.6 & 1.22 & 1.21 & 1.22 & 1.21 & 85.6 & 0.98 & 0.98 & 0.98 & 0.98 \\
\hline 78.8 & 1.21 & 1.20 & 1.21 & 1.20 & 85.8 & 0.98 & 0.98 & 0.98 & 0.98 \\
\hline 79.0 & 1.20 & 1.20 & 1.20 & 1.20 & 86.0 & 0.97 & 0.97 & 0.97 & 0.98 \\
\hline 79.2 & 1.20 & 1.19 & 1.19 & 1.19 & 86.2 & 0.97 & 0.97 & 0.97 & 0.97 \\
\hline 79.4 & 1.19 & 1.18 & 1.19 & 1.18 & 86.4 & 0.96 & 0.97 & 0.96 & 0.97 \\
\hline 79.6 & 1.18 & 1.17 & 1.18 & 1.17 & 86.6 & 0.96 & 0.96 & 0.96 & 0.96 \\
\hline 79.8 & 1.17 & 1.17 & 1.17 & 1.16 & 86.8 & 0.96 & 0.96 & 0.96 & 0.96 \\
\hline 80.0 & 1.16 & 1.16 & 1.16 & 1.16 & 87.0 & 0.95 & 0.95 & 0.95 & 0.95 \\
\hline 80.2 & 1.15 & 1.15 & 1.15 & 1.15 & 87.2 & 0.95 & 0.95 & 0.95 & 0.95 \\
\hline 80.4 & 1.15 & 1.14 & 1.15 & 1.14 & 87.4 & 0.94 & 0.94 & 0.94 & 0.94 \\
\hline 80.6 & 1.14 & 1.14 & 1.14 & 1.13 & 87.6 & 0.94 & 0.94 & 0.94 & 0.94 \\
\hline 80.8 & 1.13 & 1.13 & 1.13 & 1.13 & 87.8 & 0.93 & 0.93 & 0.93 & 0.93 \\
\hline 81.0 & 1.12 & 1.12 & 1.12 & 1.12 & 88.0 & 0.93 & 0.93 & 0.93 & 0.93 \\
\hline 81.2 & 1.12 & 1.11 & 1.12 & 1.11 & 88.2 & 0.93 & 0.93 & 0.93 & 0.93 \\
\hline 81.4 & 1.11 & 1.11 & 1.11 & 1.11 & 88.4 & 0.92 & 0.92 & 0.92 & 0.92 \\
\hline 81.6 & 1.10 & 1.10 & 1.10 & 1.10 & 88.6 & 0.92 & 0.92 & 0.92 & 0.92 \\
\hline 81.8 & 1.10 & 1.09 & 1.10 & 1.09 & 88.8 & 0.91 & 0.91 & 0.91 & 0.91 \\
\hline & & & & & 89.0 & 0.91 & 0.91 & 0.91 & 0.91 \\
\hline
\end{tabular}

Table 8 Coefficients $C_{i}$ in equation (6) for the 110 and 112 reflections (slit system $: 2^{\circ}-0.15 \mathrm{~mm}-2^{\circ}$, goniometer radius $: 185 \mathrm{~mm}$ ).

\begin{tabular}{|c|c|c|c|c|}
\hline & \multicolumn{2}{|c|}{ Si $10 \%$} & \multicolumn{2}{|c|}{ Si $20 \%$. } \\
\hline & $\mathrm{Ni}$ filter & Monochromator & Ni filter & Monochromator \\
\hline $\mathrm{C}_{1}$ & 61.817784 & 57.233501 & 61.608241 & 57.039467 \\
\hline $\mathrm{C}_{2}$ & -2.4387954 & -2.2491108 & -2.4304493 & -2.2414119 \\
\hline $\mathrm{C}_{3}$ & $3.7563103 \times 10^{-2}$ & $3.4581242 \times 10^{-2}$ & $3.7435223 \times 10^{-2}$ & $3.4463408 \times 10^{-2}$ \\
\hline $\mathrm{C}_{4}$ & $-2.6363368 \times 10^{-4}$ & $-2.4245787 \times 10^{-4}$ & $-2.6274529 \times 10^{-4}$ & $-2.4163817 \times 10^{-4}$ \\
\hline $\mathrm{C}_{5}$ & $7.0862065 \times 10^{-7}$ & $6.5115863 \times 10^{-7}$ & $7.0629271 \times 10^{-7}$ & $6.4900494 \times 10^{-7}$ \\
\hline
\end{tabular}

Caution: digit numbers of coefficient should be kept

プロファイルフィッティング処理では, 基本的に $\mathrm{K} \alpha_{1} \cdot \mathrm{K} \alpha_{2}$ 線 2つのピークにてフィッティング処理を行う。

決定された炭素と標準シリコンについての回折角度の間隔 $\delta_{\mathrm{Si}-\mathrm{C}}$ (角度単位) を求める。Table 2 において記した標準シリコンの回 折角 $2 \theta_{\mathrm{Si}}$ から下式によって正しい回折角 $2 \theta_{\mathrm{C}}$ を求める*6。回折角 $2 \theta$ の有効数字は, 小数点以下 3 桁とする。
*6 シリコンの 111 回折線は $\mathrm{K} \alpha_{1} \cdot \mathrm{K} \alpha_{2}$ 線が分離することはほとんどな いので, 回折角度は Table 2 の $\mathrm{K} \alpha_{\mathrm{m}}$ の值を用いる。一方, ほかの 331 拈よび422回折線の場合は, Fig.2にも示したように $K \alpha_{1} \cdot K \alpha_{2}$ 線が 分離する。したがって, $\mathrm{K} \alpha_{1}$ の回折角を角 $2 \theta_{\mathrm{Si}}$ の值とする。シリコ ンの 331 および422回折線において, $\mathrm{K} \alpha_{1} \cdot \mathrm{K} \alpha_{2}$ 線の分離が不明確な ときは計算誤差が大きい。 

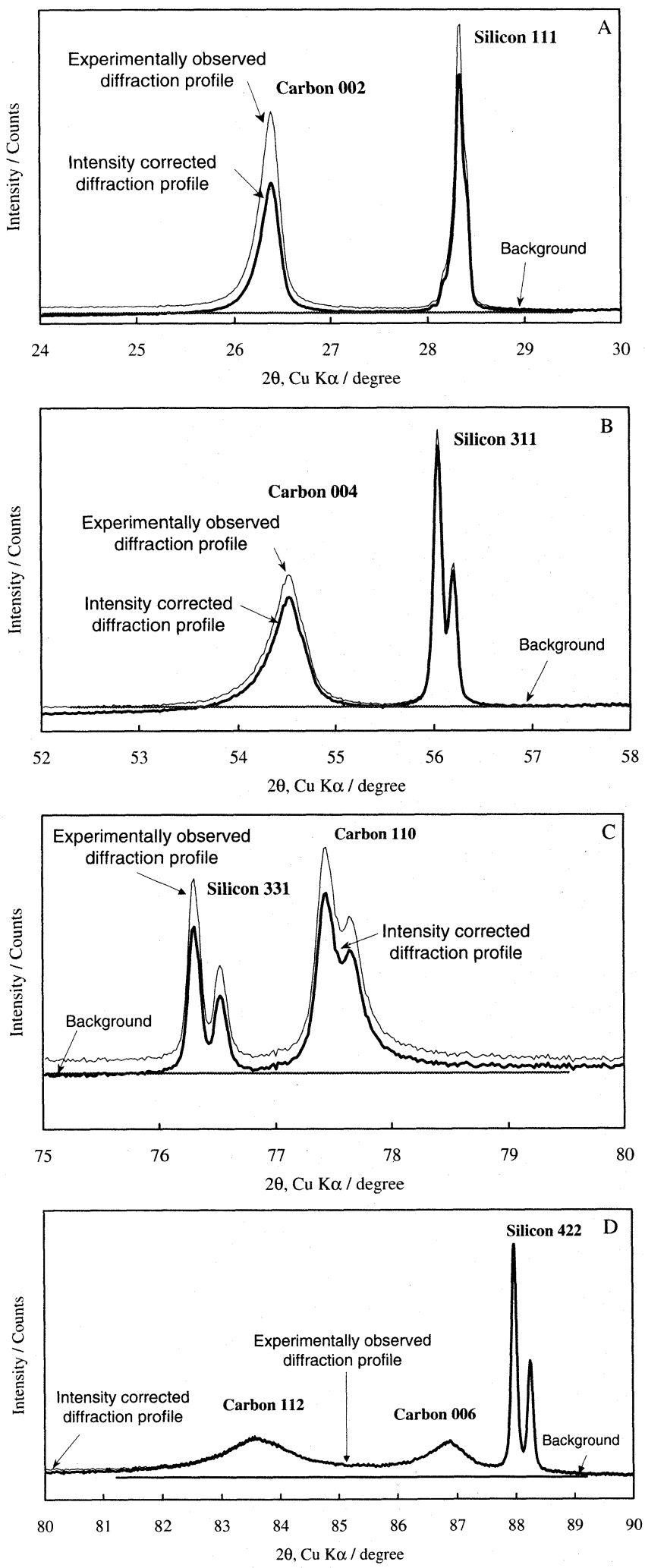

Fig.1 A : Example of the intensity correction of the 002 reflection and the determination of the background. B : Example of the intensity correction of the 004 reflection and the determination of the background. $\mathrm{C}$ : Example of the intensity correction of the 110 reflection and the determination of the background. D : Example of the intensity correction of 006 and 112 reflections, and the determination of the background.
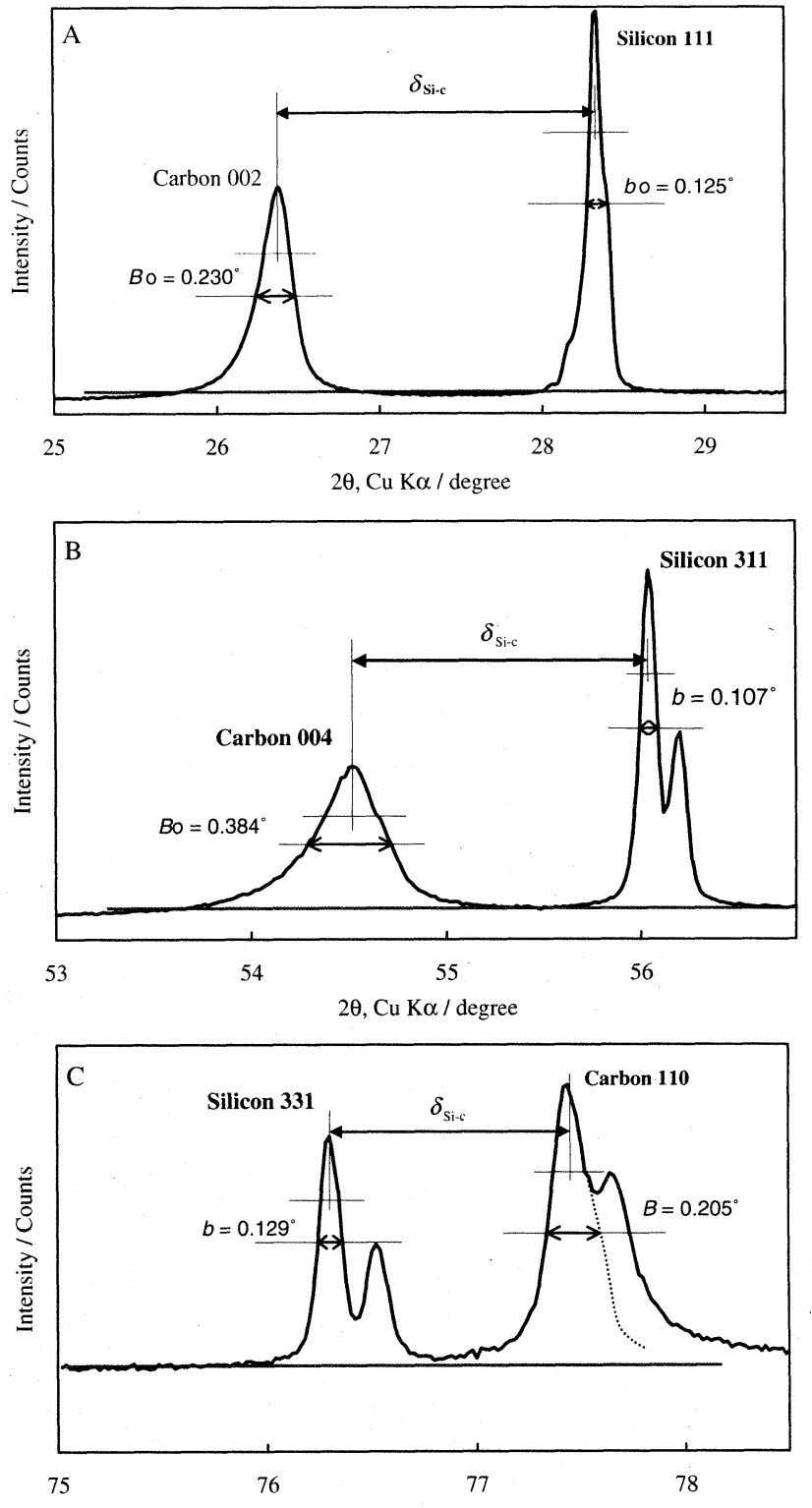

$2 \theta, \mathrm{Cu} \mathrm{K \alpha / \text {degree }}$

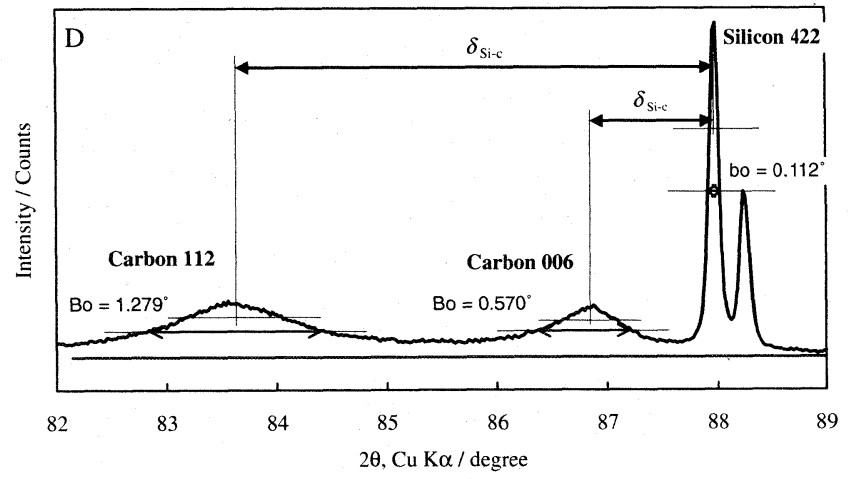

Fig.2 A : Example of the determination of $B_{0}$ for carbon, bo for silicon and diffraction angle shift $\delta_{\mathrm{Si}-\mathrm{C}}$ for the case of the 002 reflection. B : Example of the determination of $B_{0}$ for carbon, $b_{\mathrm{o}}(b)$ for silicon and diffraction angle shift $\delta_{\mathrm{Si}-\mathrm{C}}$ for the case of the 004 reflection. $C$ : Example of the determination of $B_{0}(\mathrm{~B})$ for carbon, $b_{\mathrm{o}}(b)$ for silicon and diffraction angle shift $\delta_{\mathrm{Si}-\mathrm{C}}$ for the case of the 110 reflection. D: Example of the determination of $B_{0}$ for carbon, $b_{0}(b)$ for silicon and diffraction angle shift $\delta_{\mathrm{Si}-\mathrm{C}}$ for the case of the 006 and 112 reflections. 
002, 004, 006

および112回折線の場合 $2 \theta_{\mathrm{Si}}-\delta_{\mathrm{Si}-\mathrm{C}}=2 \theta_{\mathrm{C}}$

110 回折線の場合 $\quad 2 \theta_{\mathrm{Si}}+\delta_{\mathrm{Si}-\mathrm{C}}=2 \theta_{\mathrm{C}}$

炭素について測定された $2 \theta_{\mathrm{C}}$ を用いてBraggの式 ((9) 式) から 面間隔 $d_{002}, d_{004}, d_{110}, d_{112}$ および $d_{006}$ を計算する。
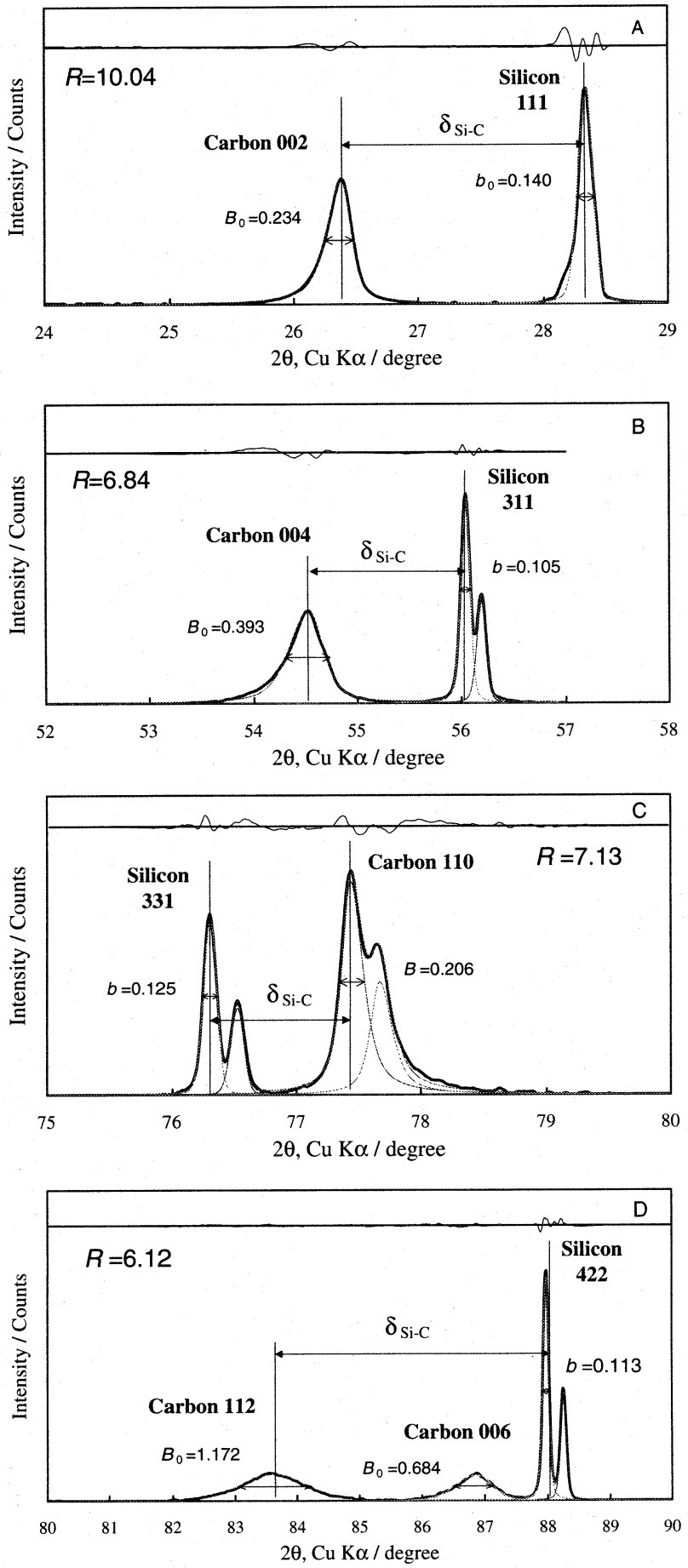

Fig.3 A : Example of a drawing for the case of the 002 reflection by a profile fitting procedure. $\mathrm{B}$ : Example of a drawing for the case of the 004 reflection by a profile fitting procedure. $\mathrm{C}$ : Example of a drawing for the case of the 110 reflection by a profile fitting procedure. $\mathrm{D}$ : Example of a drawing for the case of the 006 and 112 reflections by a profile fitting procedure. $d=\lambda / 2 \sin \theta_{C} \quad[\mathrm{~nm}]$

ここで計算に使用する $\mathrm{CuK} \alpha$ 線の波長 $\lambda$ は, 炭素の回折ピーク プロファイルの $\mathrm{K} \alpha_{1} \cdot \mathrm{K} \alpha_{2}$ 線の分離が非常に明瞭な場合 : $\lambda_{1}=$ $0.154059292 \mathrm{~nm} * 7$, 分離が不明確な場合： $\lambda_{\mathrm{m}}=0.154186661 \mathrm{~nm}$ を代入する。

さらにこれらの面間隔を格子定数 $a_{0}$ および $c_{0}$ に換算する。

$$
\begin{aligned}
& c_{0}(002)=2 d_{002}, \\
& c_{0}(004)=4 d_{004}, \\
& c_{0}(006)=6 d_{006}, \\
& a_{0}(110)=2 d_{110}
\end{aligned}
$$

\section{（3）結晶子の大きさの決定*8}

強度補正した回折ピークプロファイルからその半価幅を測定 し, 結晶子の大きさを決定する。Fig.2にて示したように, ベースラ インから図形の高さ $1 / 2$ の位置で図形の幅, すなわち半価幅を角 度単位 $\left[^{\circ}\right.$ (degree) $]$ で測定する。

このとき, 標準シリコン 111 回折ピークの半価幅が $0.2^{\circ}$ 以下で あることが必須条件である。さらに, シリコンの 331 および 422 回折線のピークプロファイルが $\mathrm{Cu} \mathrm{K} \alpha_{1}, \mathrm{Cu} \mathrm{K} \alpha_{2}$ 線に分離されてい なければならない。

標隼シリコン 111 回折線および炭素の各回折線の $\mathrm{K} \alpha_{1} \cdot \mathrm{K} \alpha_{2}$ 回折 線が分離していない場合, $K \alpha_{1} \cdot K \alpha_{2}$ 二重線の補正をRachingerの方 法1)を基礎とした以下の手法によって行う必要がある。

炭素についての観測半価幅を $B_{0}$, 標準シリコンについての観測 半価幅を $b_{0}$ とする。各回折線について Table 9 に示した $\Delta$ 值から $\Delta / b_{0}$ および $\Delta / B_{0}$ を計算し，（11）式を用いて $b / b_{0}$ および $B / B_{0}$ を求 める。この $b / b_{0}$ および $B / B_{0}$ から, $\mathrm{K} \alpha_{1} \cdot \mathrm{K} \alpha_{2}$ 二重線の補正を行っ た半価幅 $b$ および $B$ を計算する2),3)。

$$
\begin{aligned}
& b / b_{0} \text { or } B / B_{0}=0.9994107+0.01437434 \cdot u-1.2975834 \cdot u^{2} \\
& +2.96697536 \cdot u^{3}-9.4611055 \cdot u^{4} \\
& +8.1659185 \cdot u^{5} \\
& \text { ただし }, u=\Delta / b_{0} \text { または } \Delta / B_{0}
\end{aligned}
$$

Table $9 \Delta$ values for each reflection of carbon and silicon.

\begin{tabular}{|c|c|c|c|}
\hline \multicolumn{2}{|c|}{ Carbon } & \multicolumn{2}{c|}{ Silicon } \\
\hline$h k l$ & $\Delta\left(^{\circ}\right)$ & $h k l$ & $\Delta\left(^{\circ}\right)$ \\
\hline 002 & 0.067 & 111 & 0.072 \\
\hline 004 & 0.147 & 311 & 0.152 \\
\hline 110 & 0.229 & 331 & 0.224 \\
\hline 112 & 0.255 & 422 & 0.275 \\
\hline 006 & 0.271 & & \\
\hline
\end{tabular}

*7 International Tables for X-ray Crystallography, Vol.C, International Union of Crystallography, $1999 よ り$

*8 結晶子の大きさの定義あるいはその数值の意味するものについて は, 現在まだ定説はないが,ここでは単に工学的なパラメータとし て用い得る数值として結晶子の大きさを決定する方法を制定した。 
なお, 標準シリコンの 331 および422回折線および炭素の各龱 折線が $\mathrm{K} \alpha_{1} \cdot \mathrm{K} \alpha_{2}$ 線に分離した場合は, 実測した $\mathrm{K} \alpha_{1}$ 線の半価幅 を $B$ および $b$ とし，(11）式の補正は実行しない。Fig.2Cの炭素 の 110 回折線のように, $\mathrm{K} \alpha_{1}$ ピークの先端から高角度側に想定線 を描き,その半価幅を $B$ としてもよい。標準シリコンの 331 およ び422回折線については, Fig.2C, およびFig.2D参照のこと。

つぎに, $b / B$ から (12) 式を用いて $\beta / B$ を求め, 真の半価幅 $\beta$ (角度 単位 $\left[{ }^{\circ}\right.$ (degree) $\left.]\right)$ を得る3)。

$$
\begin{aligned}
& \begin{aligned}
\beta / B= & 0.9981266-0.0681532 \cdot v-2.592769 \cdot v^{2} \\
& +2.621163 \cdot v^{3}-0.9584715 \cdot v^{4}
\end{aligned} \\
& \text { ただ }, v=b / B \text { である。 }
\end{aligned}
$$

各回折線について得られた $\beta$ から (13) 式によって結晶子の大 きさ $L$ を計算する。なお, 本法では, Scherrerの式 $L=K \lambda / \beta \cos \theta_{C}$ において, 形状因子 $K$ を 1.00 とした。

$$
\begin{array}{ll}
002 \text { 回折線の場合 } L c(002)=9.1 / \beta \\
004 \text { 回折線の場合 } L c(004)=9.9 / \beta \\
110 \text { 回折線の場合 } L a(110)=11.3 / \beta \\
112 \text { 回折線の場合 } L c(112)=4.1 / \beta \\
006 \text { 回折線の場合 } L c(006)=12.2 / \beta
\end{array}
$$

単位はすべて $[\mathrm{nm}]$

002, 004 および006回折線から求めた $L$ はともに結晶子の $c$ 軸 方向の厚み $L c$ を与え, 110 回折線から求めた $a$ 軸方向の幅 $L a$ を与. え, また, 112 回折線から決めた $L$ は三次元的な黒鉛結晶の $c$ 軸方向 の厚み*9を表す。

\section{0. 測定結果の表記}

\section{（1）格子定数}

学振法における回折角度は,「ピーク高さ $2 / 3$ のピーク幅の中 点」とする。したがって, プロファイルフィッティング処理の場 合, 解析結果より得られたピークトップの角度から算出された格子 定数には，(ピークトップ）と併記することとする。

ただし, 非対称性を考慮したフィッティング関数の变数から補 正して「ピーク高さ $2 / 3$ のピーク幅の中点」を求めた場合は, 明記 しなくてよい。

1つの試料について, 7. 回折ピークプロファイルの測定 (すな わち, 試料をサンプルフォルダに充填する操作) 以下の操作を 3 回以上繰返して行うことを推奨する。そして, 得られた格子定 数の算術平均值を表記する。

*9 112 回折線から直接求められる $L$ は [112] 方向の結晶子の大きさを与 えるので,それを $c$ 軸方向の大きさに換算したものを $L c(112)$ とした。 *10 低結晶性のサンプルの場合, 例えば, 平均面間隔 $d_{002}$ が $0.3440 \mathrm{~nm}$ よ り大きい場合, 誤差は小数点以下 3 桁目まで及ぶ可能性がある。

*11 Lc (002), Lc (004), Lc (006) の值は一般には一致しないので, 測定可 能なときはそれぞれを表記することが望ましい。
002,004 および006 回折線から求めた面間隔 $d$ は $d_{002}, d_{004}$ お よび $d_{006}$ とする。それらを 2,4 および 6 倍した值は, $c$ 軸方向の格 子定数 $c_{0}$ であり $, c_{0}(002), c_{0}(004)$ および $c_{0}(006)$ と表現する。 一般に $c$ 軸長よりその半分の值の炭素六角網面の間隔 $d_{002}$ で表 記される。002,004および006回折線からそれぞれ $d_{002}(002)$, $d_{002}(004)$ および $d_{002}(006)$ を求める。

110 回折線から $a$ 軸長は $a_{0}(110)$ として, また 112 回折線から 求めた面間隔 $d$ は $d_{112}$ として記す。

各面間隔および格子定数の有効数字は 4 桁 $(\mathrm{nm}$ 単位で, 小数点 以下 4 桁) とする*10。

\section{（2）結晶子の大きさ}

1つの試料について7. 回折ピークプロファイルの測定 (すな わち, 試料をサンプルフォルダに充填する操作) 以下の操作を 5 回以上繰返して行うことを推奨する。そして, 得られた結晶子 の大きさの算術平均値を表記すること。

結晶子の大きさの数值の有効数字は, 整数 2 桁までとする。た だし, 小数点以下は表記しない。

002, 004 および006回折線から求めた $L c は L c(002), L c(004)$ および $L c(006)$ として*11, 110 回折線から求めた $L a$ は $L a(110)$ として,また 112 回折線から求めた $L$ は $L c(112)$ として記す。

さらに可能であれば, 参考として標準偏差值 $s$ たは変動係数 $C V$ を測定平均值の後に括弧内の数值で付記をする。その場合は, 次の (14) 式および (15) 式によって算出し, 標準偏差值の有効数 字は整数 2 桁とし, 变動係数は, 小数点以下 2 桁に丸める。

$$
\begin{aligned}
& s=\sqrt{\frac{\sum(x-\bar{x})^{2}}{n-1}} \\
& C V=\frac{s}{\bar{x}} \times 100 \cdots \cdots
\end{aligned}
$$

ここで, $s$ : 標準偏差, $C V$ : 変動係数 $(\%), x$ : 個々の測定値, $n$ : 測定数, そして $\bar{x}:$ 平均值である。

解析精度の保証のため, 標準シリコンの回折ピーク半価幅の值 は必ず記録することとする。

\section{（3）プロファイルフィッティング法の変数}

プロファイルフィッティング法による解析には, この手法独自の 解析変数が存在する。そのなかでもフィッティング結果の $R$ 因 子および $\mathrm{K} \alpha_{1}$ と $\mathrm{K} \alpha_{2}$ の強度比 (分離係数) を記録しておくこと。 表記例 :

\section{等方性黒鉛材料 $\mathrm{G} 347$}

【机上法 (Carbon-X) によって解析】

$d_{002}(002): 0.3367 \mathrm{~nm}, L c(002): 47 \mathrm{~nm}(8 \mathrm{~nm})$ $d_{002}(004): 0.3365 \mathrm{~nm}, L c(004): 30 \mathrm{~nm}(6 \mathrm{~nm})$ $a_{0}(110): 0.2461 \mathrm{~nm}, L a(110): 65 \mathrm{~nm}(20 \mathrm{~nm})$ $d_{112}(112): 0.1156 \mathrm{~nm}, L c(112): 4 \mathrm{~nm}(1 \mathrm{~nm})$ $d_{002}(006): 0.3365 \mathrm{~nm}, L c(006): 15 \mathrm{~nm}(4 \mathrm{~nm})$ 
【プロファイルフィッティング法 (Carbon Analyzer G series) に よって解析】

$d_{002}(002): 0.3362 \mathrm{~nm}($ ピークトップ), $L c(002): 48 \mathrm{~nm}(9 \mathrm{~nm})$ $d_{002}(004): 0.3362 \mathrm{~nm}($ ピークトップ), Lc (004) : 26nm $(4 \mathrm{~nm})$ $a_{0}(110): 0.2462 \mathrm{~nm}($ ピークトップ), La (110) : $110 \mathrm{~nm}(28 \mathrm{~nm})$ $d_{112}(112): 0.1156 \mathrm{~nm}$ (ピークトップ), Lc (112): $4 \mathrm{~nm}(1 \mathrm{~nm})$ $d_{002}(006): 0.3361 \mathrm{~nm}($ ピークトップ), $L c(006): 18 \mathrm{~nm}(4 \mathrm{~nm})$

\section{(4) 測定結果の整理}

測定結果には, 上述した数值結果のほかに, 次の事項のうちか ら必要なものを記載する

測定年月日

測定者

試料名

標準シリコン粉末の試薬名

装置の名称, 形式

試料調整方法

測定方法とその条件 a） X線管球の作動条件（電流, 電圧）

b) ゴニオメータの走査条件

c）付属装置の作動条件

d) ゴニオ半径

e) スリット系

解析方法とその条件

その他必要条件

a）シリコンの各回折線の半価幅とその平均值

b) プロファイルフィッティング法による解析の場合, フィッ ティング結果の $R$ 因子および $\mathrm{K} \alpha_{1}$ と $\mathrm{K} \alpha_{2}$ の強度比 (分離係 数)

c）付属装置の作動条件

\section{文 献}

1) WA. Rachinger, J. Sci. Instrum. 35, 1627 (1948).

2) FW. Jones, Pro. Roy. Soc. Lond. A 166, 16 (1938).

3) LE. Alexander, J. Appl. Phys. 25, 155 (1954). 